University of Nebraska - Lincoln

DigitalCommons@University of Nebraska - Lincoln

USDA National Wildlife Research Center - Staff Publications
U.S. Department of Agriculture: Animal and Plant Health Inspection Service

2013

\title{
ORAL RABIES VACCINATION VARIATION IN TETRACYCLINE BIOMARKING AMONG OHIO RACCOONS
}

Timothy P. Algeo

USDA/APHIS/Wildlife Services

Gary Norhenberg

USDA/APHIS/Wildlife Services

Robert Hale

USDA/APHIS/Wildlife Services

Andrew Montoney

USDA/APHIS/Wildlife Services

Richard B. Chipman

USDA/APHIS/Wildlife Services

See next page for additional authors

Follow this and additional works at: https://digitalcommons.unl.edu/icwdm_usdanwrc

Part of the Life Sciences Commons

Algeo, Timothy P.; Norhenberg, Gary; Hale, Robert; Montoney, Andrew; Chipman, Richard B.; and Slate, Dennis, "ORAL RABIES VACCINATION VARIATION IN TETRACYCLINE BIOMARKING AMONG OHIO RACCOONS" (2013). USDA National Wildlife Research Center - Staff Publications. 1893.

https://digitalcommons.unl.edu/icwdm_usdanwrc/1893

This Article is brought to you for free and open access by the U.S. Department of Agriculture: Animal and Plant Health Inspection Service at DigitalCommons@University of Nebraska - Lincoln. It has been accepted for inclusion in USDA National Wildlife Research Center - Staff Publications by an authorized administrator of DigitalCommons@University of Nebraska - Lincoln. 


\section{Authors}

Timothy P. Algeo, Gary Norhenberg, Robert Hale, Andrew Montoney, Richard B. Chipman, and Dennis Slate 


\title{
ORAL RABIES VACCINATION VARIATION IN TETRACYCLINE BIOMARKING AMONG OHIO RACCOONS
}

\author{
Timothy P. Algeo, ${ }^{1,5}$ Gary Norhenberg, ${ }^{2}$ Robert Hale, ${ }^{3}$ Andrew Montoney, ${ }^{4}$ \\ Richard B. Chipman, ${ }^{1}$ and Dennis Slate ${ }^{1}$ \\ ${ }^{1}$ USDA/APHIS/Wildlife Services, National Rabies Management Program, 59 Chenell Drive, Suite 2, Concord, \\ New Hampshire 03301, USA \\ 2 USDA/APHIS/Wildlife Services, Saint Paul Downtown Airport, 644 Bayfield Street, Suite 215, Saint Paul, \\ Minnesota 55107, USA \\ ${ }^{3}$ USDA/APHIS/Wildlife Services, National Rabies Management Program, 6929 Americana Parkway, \\ Reynoldsburg, Ohio 43068, USA \\ ${ }^{4}$ USDA/APHIS/Wildlife Services, 6929 Americana Parkway, Reynoldsburg, Ohio 43068, USA \\ ${ }^{5}$ Corresponding author (email: timothy.p.algeo@aphis.usda.gov)
}

ABSTRACT: Oral rabies vaccination (ORV) programs have traditionally relied on tetracycline marking as an index to bait uptake. Whether tetracycline serves well in this capacity depends on its deposition affinity and ability to be detected consistently among tissues selected for analysis from target species. We evaluated samples from 760 hunter-harvested raccoons (Procyon lotor) from areas in Ohio where ORV had been conducted during 1998, 1999, and 2001. Tetracycline marking was evaluated within and among first premolar (PM1), second premolar (PM2), and canine (CN) teeth, and mandibular bone (MB) by side (left versus right); and by tissue type. Tetracycline detection ranged from 6.5\% in PM1 in 1998 to 56.3\% in right-side MB in 2001. PM1 teeth were less frequently marked (21.7\%) than PM2 (27.7\%), CN (33.0\%), or MB (42.0\%). Tetracycline detection was similar in left and right PM1, PM2, and CN teeth, but differed in MB. Tetracycline marking was significantly different among all tissue types.

Key words: Bait uptake, biomarker, oral rabies vaccination, ORV, Procyon lotor, raccoon, tetracycline hydrochloride.

\section{INTRODUCTION}

Wildlife disease or population management programs often require the identification of animals that have consumed baits, such as oral rabies vaccine (ORV) baits (baits). Tetracycline hydrochloride (tetracycline) is a commonly used compound for this purpose, and is detectable 2-5 days postconsumption (Hanlon et al., 1989) by ultraviolet microscopy of crosssectioned teeth (Johnston et al., 1987). Consequently, tetracycline has an extensive history of use in oral vaccination and predator control (Linhart and Kenelly, 1967; Hanlon et al., 1989; Bachmann et al., 1990; Hable et al., 1992; Creekmore et al., 1994; Farry et al., 1998; Johnston et al., 2005; Slate et al., 2005; Ramey et al., 2008; Rosatte et al., 2008). More specifically, tetracycline has been used to assess bait uptake as part of oral vaccination campaigns and research in red foxes (Vulpes vulpes; Johnston and Voight, 1982; Niin et al., 2008), striped skunks (Mephitis mephitis; Johnston and Voight, 1982), raccoons (Procyon lotor; Rupprecht et al., 1987; Rosatte et al., 2009), coyotes (Canis latrans; Linhart and Kinelly, 1967), raccoon dogs (Nyctereutes procyonoides; Niin et al., 2008), and feral swine (Sus scrofa; Campbell et al., 2011). For other research purposes (e.g., medical research and wildlife population enumeration), tetracycline biomarking has been used among the Muridae (Buyske et al., 1960), Otariidae (Yagi et al., 1963), and Ursidae (Garshelis and Visser, 1997; Immell et al., 2008; Peacock et al., 2011). Despite the presence of relatively low background levels of tetracycline among carnivores in ORV-naive areas ( $<1 \%$ from Nunan et al., 1994; $13 \%$ from Rosatte et al., 2008), and the fact that some tetracycline contained in ORV baits is lost through conversion to epitetracycline (Johnston et al., 2005), tetracycline remains a useful program assessment tool in the absence of viable alternatives.

The US Department of Agriculture, Animal and Plant Health Inspection Service, 
Wildlife Services (WS) National Rabies Management Program (NRMP) conducts several cooperative ORV programs, some of which use fishmeal polymer baits laden with a tetracycline biomarker. Characterizing tetracycline deposition in teeth and mandibular bone in raccoons is important for evaluating ORV program performance. We evaluated tetracycline as an ORV biomarker among 760 hunter-harvested raccoons from areas where ORV had been conducted in Ohio during $1998(n=158), 1999(n=402)$, and 2001 ( $n=200)$ by side (left versus right), age, and tissue type (teeth and mandibular bone $[\mathrm{MB}]$ ) to determine the most appropriate tissue to assess bait uptake.

\section{MATERIALS AND METHODS}

Ohio trappers and hunters provided WS with raccoon heads from Ashtabula (19981999, 2001), Jefferson (1998-1999, 2001), Trumball (2001), and Columbiana (2001) counties for this study, respectively. Sex, body size, known ages, and serological data were not available for these raccoons. Raccoon maxillary first premolar (PM1), second premolar (PM2), and canine $(\mathrm{CN})$ teeth, and $\mathrm{MB}$ samples were removed, labeled, and prepared for shipment to Matson's Laboratory, LLC (Milltown, Montana, USA) per laboratory instructions for tetracycline detection and aging. Thin $(\sim 100 \mu \mathrm{m})$, nondecalcified sections were cut from raccoon teeth (Struers Minitom ${ }^{\mathrm{TM}}$ sectioning saw with wafered $10-\mathrm{cm}$ diamond blades; Struers, Inc., Cleveland, Ohio, USA) and permanently mounted on glass microscope slides that were illuminated with ultraviolet light and examined at $100 \times$ with a Leitz ${ }^{\mathrm{TM}}$ compound microscope (Leica Microsystems, GmbH, Wetzlar, Germany) for tetracycline detection (G. Matson, pers. comm.). Raccoon age was assessed through the cementum method (Johnston et al., 1987). Reported findings included the presence/absence of one or more tetracycline marks, and the estimated raccoon age for each sample submitted.

For 2001, samples from both sides of the heads of trapped raccoons were available. We used McNemar's tests (McDonald, 2009) to compare detected post-ORV tetracycline between paired left and right maxillary teeth and MB within individual raccoons to determine whether selection of side of raccoon head could affect population-level tetracyclinebased assessments of ORV bait uptake. When teeth from both sides were statistically equivalent, we arbitrarily selected the right side only for the 2001 tissues included in further analyses despite the fact that tetracycline detection in mandibles differed. We used a Cochran's Q-test (Cochran, 1950) to compare tetracycline marking among tissue types with Wilcoxon sign tests to identify specific statistical differences among tissue types. McNemar's tests were conducted in SAS 9.1 (SAS Institute, 2002), and Cochran's Q- and Wilcoxon sign tests were conducted in $\mathrm{R}$ ( $\mathrm{R}$ Foundation for Statistical Computing, 2012).

\section{RESULTS}

Tetracycline detection ranged from 6.5\% (PM1 in 1998) to $56.3 \%$ (right-side $\mathrm{MB}$ in 2001) among PM1, PM2, CN, and MB. Among raccoon teeth for which conclusive tetracycline analysis results were available for all four tissues $(n=719)$, PM1 teeth were less frequently marked $(21.7 \%)$ than PM2 $(27.7 \%$; odds ratio $[\mathrm{OR}]=0.72), \mathrm{CN}(33.0 \% ; \mathrm{OR}=$ $0.56)$, or $\mathrm{MB}(42.0 \%$; $\mathrm{OR}=0.38)$. The ORV baiting events and bait distribution densities varied among all 3 yr sampled (Table 1).

Among raccoons with conclusive tetracycline results and ages 0-8 $(n=697)$, tetracycline marking in PM1s occurred among the younger age classes, but marking was absent in raccoons $>4 \mathrm{yr}$ old. In PM2s, tetracycline detection occurred in all age classes. Among CN teeth, marking was relatively uncommon among raccoons $<1$ yr old, but then occurred at higher levels in years 1-8 than among PM1 and PM2 (Fig. 1).

Within individual raccoons from 2001, tetracycline detection was similar in left and right PM1 $(P=0.26, n=200)$, PM2 $(P=0.13, n=200)$, and $\mathrm{CN} \quad(P=0.40$, $n=200)$ raccoon teeth. However, tetracycline detection differed between MB $(P=0.02, n=197)$. Because MB is a large tissue, and sampling locations may vary and account for this difference, we arbitrarily selected right-side tissues only for the final among-tissue analyses (Fig. 2). Tetracycline detection differed among 
TABle 1. Raccoon (Procyon lotor) tooth samples from oral rabies vaccination zones in Ohio, USA, for assessment of tetracycline deposition, 1998-1999, 2001.

\begin{tabular}{|c|c|c|c|c|c|c|}
\hline Year & $\begin{array}{l}\text { Baiting } \\
\text { events }^{\mathrm{b}}\end{array}$ & Bait density $\left(\mathrm{km}^{2}\right)$ & $\begin{array}{c}\text { First premolar } \\
(\text { PM1) } \\
\text { \% Tetracycline+ }^{\mathrm{c}} \\
(n)\end{array}$ & $\begin{array}{c}\text { Second premolar } \\
\text { (PM2) } \\
\text { \% Tetracycline+ } \\
(n)\end{array}$ & $\begin{array}{c}\text { Canine }(\mathrm{CN}) \\
\text { \% Tetracycline+ } \\
(n)\end{array}$ & $\begin{array}{l}\text { Mandibular bone } \\
\text { \% Tetracycline+ } \\
(n)\end{array}$ \\
\hline 1998 & 4 & 75/100 Spring, 75 fall & $6.5(155)$ & $21.9(155)$ & $37.3(150)$ & $34.8(155)$ \\
\hline 1999 & 6 & $75 / 150 / 300$ Spring, 75 fall $^{\mathrm{b}}$ & $19.9(402)$ & $25.4(394)$ & $26.0(392)$ & $35.9(396)$ \\
\hline 2000 & 8 & $65 / 75$ Spring, fall ${ }^{\mathrm{b}}$ & NA & NA & NA & NA \\
\hline 2001 Right & 10 & $65 / 75$ Spring, fall ${ }^{\mathrm{b}}$ & $34.5(200)$ & $36.0(200)$ & $44.0(200)$ & $56.3(199)$ \\
\hline 2001 Left $^{\mathrm{a}}$ & & & $38.0(200)$ & $32.0(200)$ & $41.5(200)$ & $50.8(199)$ \\
\hline
\end{tabular}

$\mathrm{NA}=$ not applicable.

${ }^{\text {a }}$ Excluded from further analyses after determining sides were statistically equivalent in PM1, PM2, and CN teeth.

${ }^{\mathrm{b}}$ Source: Ohio Department of Health (2002).

${ }^{\mathrm{c}}+=$ positive.
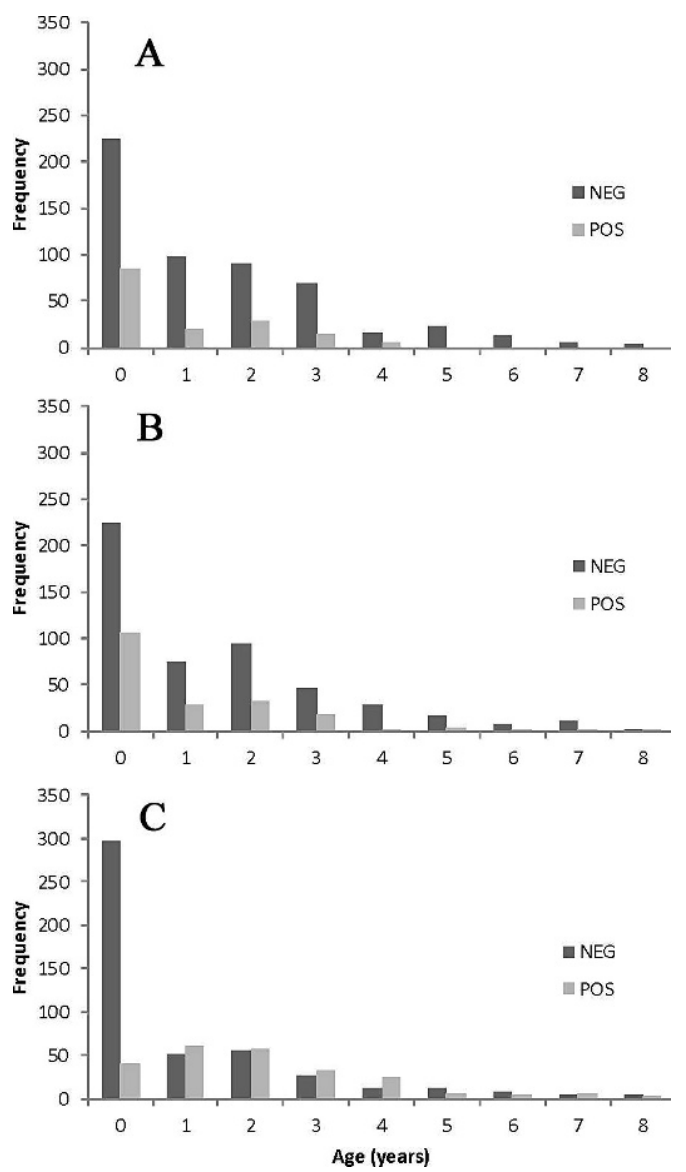

Figure 1. Tetracycline marking of (a) first premolar, (b) second premolar, and (c) canine raccoon (Procyon lotor) teeth by age in Ohio, USA, 1998, 1999 , and $2001(n=697)$. tissue types $(P<0.0001)$, and all tissue type pairs differed $(P<0.025, n=719)$.

\section{DISCUSSION}

Tetracycline deposition characteristics among raccoons are largely unknown and can potentially affect program assessment. For tetracycline detection in raccoon teeth, sufficient amounts must be ingested $(\geq 20 \mathrm{mg} / \mathrm{kg}$ ), and enough time must have elapsed before sampling (2-3 mo during growth seasons; G. Matson, pers. comm.). In our study, paired left and right MBs differed. Linhart and Kenelly (1967) demonstrated that, although tetracycline marking in coyote $\mathrm{MB}$ occurred with higher frequency than in some other tissues sampled, it was not reliably detected on

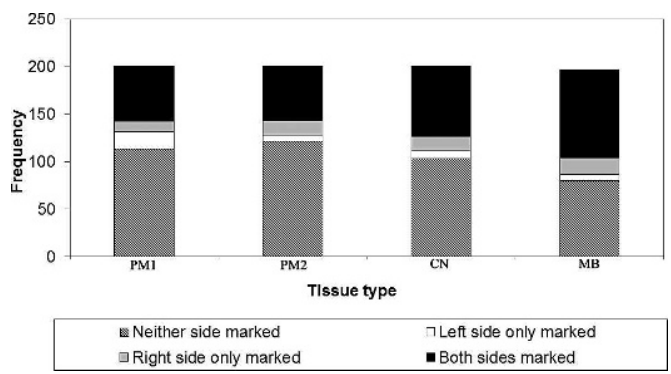

Figure 2. Distribution (between sides) of tetracycline biomarking in maxillary first premolar (PM1), second premolar (PM2), and canine (CN) teeth (all $n=200)$; and mandibular bone (MB; $n=197)$ of raccoons (Procyon lotor) in Ohio, USA, 2001. 
specific areas of the MB. However, it was most frequently detected in the region of the masseter (i.e., the coronoid process, mandibular notch, and massateric fossa), and around the bases of CN. Consequently, it is possible that unaccounted-for variation in sampling sites on raccoon MBs may account for the difference we found between sides. Regardless, MB is obviously useful only for postmortem study, and in many cases, $\mathrm{MB}$ is not the tissue selected for analysis as extraction and storage is problematic compared with teeth. Additionally, teeth are often preferred so that age may be determined from cementum annuli counts. In the event MB tissues are sampled, careful selection and standardization of sampling region might reduce this variation.

Age was based on cementum annuli evaluation, but known age can only be determined with certainty from known birth dates. Some possible variation among tissue types in terms of age-related effects may have occurred (Fig. 1). A possible explanation is suggested by the findings of Linhart and Kennelly (1967) in coyotes that tetracycline detection in $\mathrm{CN}$ teeth from animals $>5.5 \mathrm{yr}$ old did not occur, despite being detected in adjacent bone, leading them to conclude that dentin growth was reduced or ceased beyond that age in coyotes. Variation in the number of baiting episodes among years; time-lags between bait distribution, bait uptake, and sample collection; raccoon population density, age structure (Linhart and Kennelly, 1967), and sex (Buyske et al., 1960); and condition and age of tetracycline within bait lots may be confounding. In Ontario, Rosatte et al. (2008) found age effects in some, but not all, years for samples they studied, suggesting variation in this phenomenon within populations.

Tetracycline detection among tissue types differed, with more frequent biomarking in PM2 and CN teeth, and MB than in PM1 teeth. It is impractical on ethical grounds to extract $\mathrm{MB}$ and $\mathrm{CN}$ from live-caught animals to be released, and double-rooted PM2s are generally only extractable through a more intrusive and time-consuming field procedure than are PM1 teeth. Consequently, PM1s continue to be the most acceptable, least intrusive sample to collect from livetrapped raccoons to determine specific age cohort and the presence of tetracycline marking. However, among dead or hunter-/trapper-harvested animals, $\mathrm{CN}$ or MB should be considered superior for biomarker uptake and evaluation.

Concerns over antibiotic resistance are mounting within the medical and veterinary communities (Chopra and Roberts, 2001; Teuber, 2001). We encourage continued efforts to discover suitable nonantibiotic biomarking agents, as well as efforts to include biomarkers in the coated sachet (CS) currently used most extensively in ORV in the United States. Further study is also indicated to determine if tetracycline deposition varies among raccoons on the basis of body size, sex, age, tetracycline degradation in ORV baits exposed to specific environmental conditions (Johnston et al., 2005), habitat features, MB sampling locations, or ORV operational variables (e.g., time of year for baiting).

Biomarkers provide a means to help evaluate the delivery of vaccines or other substances (Johnston and Voight, 1982; Rupprecht et al., 1987; Creekmore et al., 1994; Farry et al., 1998; Rosatte et al., 2008). The presence of a biomarker in animals that also have rabies virus neutralizing antibodies provides stronger supporting evidence that the antibody response was vaccine induced (WHO, 2005). However, questions remain about bait uptake with tetracycline as a biomarker in skunks (Rosatte et al., 2009).

Ideally, all baits should include a safe and effective biomarker. In the United States, ORV baiting has transitioned toward the use of the CS, which does not contain a biomarker. However, the fishmeal polymer bait continues to be 
applied in ground-baiting operations in the United States as well as in some areas baited by helicopter, and with bait stations (Boulanger et al., 2006). Because of the importance of measuring bait uptake, and the relationship between biomarking and vaccine-induced antibody responses, biomarkers continue to be a subject of research and development (Fry et al., 2010). Our results support the continued extraction and analysis of PM1 teeth from live-trapped animals to be released, despite the limitations described. The $\mathrm{CN}$ or carefully selected MB tissues should be considered for evaluation from dead raccoons.

\section{ACKNOWLEDGMENTS}

We acknowledge the efforts of the US Department of Agriculture (USDA), Animal and Plant Health Inspection Service (APHIS), WS Ohio field staff; K. Nelson (USDA, APHIS, WS NRMP), and G. Matson and staff (Matson's Laboratory, LLC) for significant contributions to this manuscript. We also thank the Editor-in-Chief, Assistant Editor, and anonymous reviewers for helpful suggestions that improved this paper.

\section{LITERATURE CITED}

Bachmann P, Bramwell RN, Fraser SJ, Gilmore DA, Johnston DH, Lawson KF, MacInnes CD, Matejka FO, Miles HE, Pedde MA, et al. 1990. Wild carnivore acceptance of baits for delivery of liquid rabies vaccine. J Wildl Dis 26 (4): 486-501.

Boulanger JR, Bigler LL, Curtis PD, Lein DH, Lembo AJ, Jr. 2006. A polyvinyl chloride bait station for dispensing rabies vaccine to raccoons in suburban landscapes. Wildl Soc B 34 (4): 1206-1211.

Buyske DA, Eisner HJ, Kelly RG. 1960. Concentration and persistence of tetracycline and chlorotetracycline in bone. J Pharmacol Exp Ther 130: 150-156.

Campbell TA, Long DB, Massei G. 2011. Efficacy of the boar-operated system to deliver baits to feral swine. Prev Vet Med 98: 243-249.

Chopra I, Roberts M. 2001. Tetracycline antibiotics: Mode of action, applications, molecular biology, and epidemiology of bacterial resistance. Microbiol Mol Biol R 65 (2): 232-260.

Cochran WG. 1950. The comparison of percentages in matched samples. Biometrika 37 (3-4): 256-266.

Creekmore TE, Linhart SB, Corn JL, Whitney MD, Snyder BD, Nettles VF. 1994. Field evaluation of baits and baiting strategies for delivering oral vaccine to mongooses in Antigua, West Indies. $J$ Wildl Dis 30 (4): 497-505.

Farry SC, Henke SE, Beasom SL, Fearneyhough MG. 1998. Efficacy of bait distributional strategies to deliver canine rabies vaccines to coyotes in southern Texas. J Wildl Dis 34 (1): 23-32.

Fry TL, Atwood TC, Dunbar MR. 2010. Evaluation of rhodamine $\mathrm{B}$ as a biomarker for raccoons. Hum-Wildl Interact 4 (2): 275-282.

Garshelis DL, Visser LG. 1997. Enumerating megapopulations of wild bears with an ingested biomarker. J Wildl Manage 61 (2): 466-480.

Hable CP, Hamir AN, Snyder DE, Joyner R, French J, Nettles V, Hanlon C, Rupprecht CE. 1992. Prerequisites for oral immunization of freeranging raccoons (Procyon lotor) with a recombinant rabies virus vaccine: Study site ecology and bait system development. J Wildl Dis 28 (1): 64-79.

Hanlon CL, Hayes DE, Hamir AN, Snyder DE, Jenkins S, Hable CP, Rupprecht CE. 1989. Proposed field evaluation of a rabies recombinant vaccine for raccoons (Procyon lotor): Site selection, target species characteristics, and placebo baiting trials. J Wildl Dis 25 (4): 555567.

Immell D, Jackson DH, Green RL. 2008. The effectiveness of tetracycline as a marker to estimate black bear numbers in Oregon. Wildlife Technical Report 001-2008. Oregon Department of Fish and Wildlife, Roseburg, Oregon, USA, $10 \mathrm{pp}$.

Johnston DH, Voigt DR. 1982. A baiting system for the oral rabies vaccination of wild foxes and skunks. Comp Immunol Microbiol 5 (1-3): 185186.

Johnston DH, Joachim DG, Bachmann P, Kardong KV, Stewart REA, Dix LM, Strickland MA, Watt ID. 1987. Aging furbearers using tooth structure and biomarkers. In: Wild furbearer management and conservation in North America, Novak M, Baker JA, Obbard ME, Malloch B, editors. Ontario Trappers Association, North Bay, Ontario, Canada, pp. 228-243.

Johnston JJ, Primus TM, Buettgenbach T, Furcolow CA, Goodall MJ, Slate D, Chipman RB, Snow JL, Deliberto TJ. 2005. Evaluation and significance of tetracycline stability in rabies vaccine baits. J Wildl Dis 41 (3): 549-558.

Linhart SB, Kenelly JJ. 1967. Fluorescent bone labeling of coyotes with demethylchlortetracycline. J Wildl Manage 31 (2): 317-321.

McDonald JH. 2009. Handbook of biological statistics, 2nd Ed. Sparky House Publishing, Baltimore, Maryland, $319 \mathrm{pp}$

Niin E, Laine M, Guiot AL, Demerson JM, Cliquet F. 2008. Rabies in Estonia: Situation before and after the first campaigns of oral vaccination of wildlife with SAG2 vaccine bait. Vaccine 26 (2930): 3556-3565. 
Nunan CP, Macinnes CD, Bachmann P, Johnston DH, Watt ID. 1994. Background prevalence of tetracycline-like fluorescence in teeth of free ranging red foxes (Vulpes vulpes), striped skunks (Mephitis mephitis), and raccoons (Procyon lotor) in Ontario, Canada. J Wildl Dis 30 (1): 112-114.

Ohio Department of Health. 2002. Oral rabies vaccination history in Ohio. www.odh.ohio.gov/ /media/ODH/ASSETS/Files/dis/oral\%20rabies\% 20vaccination/orvhistory1997-2001.ashx. Accessed July 2012.

Peacock E, Titus K, Garshelis DL, Peacock MM, Kuc M. 2011. Mark-recapture using tetracycline and genetics reveal record-high bear density. J Wildl Manage 75 (6): 1513-1520.

R Foundation for Statistical Computing. 2012. The R Project for Statistical Computing, version 2.15.1. www.r-project.org/. Accessed July 2012.

Ramey PC, Blackwell BF, Gates RJ, Slemons RD. 2008. Oral rabies vaccination of a northern Ohio raccoon population: Relevance of population density and prebait serology. J Wildl Dis 44 (3): 553-568.

Rosatte R, Allan M, Bachman P, Sobey K, Donovan D, Davies JC, Silver A, Bennett K, Brown L, Stevenson B, et al. 2008. Prevalence of tetracycline and rabies virus antibody in raccoons, skunks, and foxes following aerial distribution of $\mathrm{V}$-RG baits to control raccoon rabies in Ontario, Canada. J Wildl Dis 44 (4): 946-964.

Rosatte RC, Donovan D, Davies JC, Allan M, Bachman P, Stevenson B, Sobey K, Brown L,
Silver A, Bennett K, et al. 2009. Aerial distribution of ONRAB ${ }^{\circledR}$ baits as a tactic to control rabies in raccoons and striped skunks in Ontario, Canada. J Wildl Dis 45 (2): 363-374.

Rupprecht CE, Dietzschold B, Koprowski H, Johnston DH. 1987. Development of an oral wildlife rabies vaccine: Immunization of raccoons by a vaccinia-rabies glycoprotein recombinant virus and preliminary field baiting trials. In: Vaccines 87, Chanock RM, Lerner RA, Brown F, Ginsberg H, editors. Cold Spring Harbor Laboratory, Cold Spring Harbor, New York, pp. 389-392.

SAS Institute. 2002. SAS (9.1). SAS Institute, Inc., Cary, North Carolina.

Slate D, Rupprecht CE, Rooney JA, Donovan D, Lein DH, Chipman RB. 2005. Status of oral rabies vaccination in wild carnivores in the United States. Virus Res 111:68-76.

Teuber M. 2001. Veterinary use and antibiotic resistance. Curr Opin Microbiol 4 (5): 493-499.

World Health Organization. 2005. WHO expert consultation on rabies. WHO Technical Report Series 931, Geneva, Switzerland, 121 pp.

Yagi T, Nishiwaki M, Nakajima M. 1963. A preliminary study on the method of time marking with lead salt and tetracycline on the teeth of fur seal. Sci Rep Whales Res Inst 17:191-195.

Submitted for publication 16 November 2011.

Accepted 3 December 2012. 